\title{
Strategic Management Process in the Making of Financial Statements in Ministry of Foreign Affairs
}

\author{
Bambang Prayogo a * \\ ${ }^{a}$ Kementrial Luar Negeri, Indonesia
}

\section{INFORMASI ARTIKEL}

\section{ABSTRACT}

\section{Article history:}

Data submission : 10 January 2018

$1^{\text {st }}$ revision: 11 February 2018

Accepted: 13 February 2018

Available online: 12 May 2018

Keywords: strategic management, Ministry of Foreign Affairs, financial statements

\begin{abstract}
This Study aims to learn about the strategic management of Ministry of Foreign Affairs in the making of financial statement. It was carried out in Financial Bureau of Ministry od Forein Affairs in Jakarta. The result reveal that the strategic management process in the making of financial statement in the Ministry of Foreign Affairs are consist of strategy formulation, strategy implementation, and strategy evaluation. The important point to be noticed is the stakeholder analysis hadn't been used properly and the TOWS matrix wasn't used to formulate strategy development.
\end{abstract}

2018 FIA UB. All rights reserved.

\section{Introduction}

Strategic management has become an important tool for the public manager to create value and to shape the organization. Strategic management itself can be interpreted as a managerial action that tries to develop the potential of the organization in exploiting organizational opportunities that appeared to achieve organization goals that have been established. It shown since the start of the 80 s the public sector has seen a large flow of private sector principles and tools into the public sector in the attempt to increase efficiency and effectiveness. Since the 90 s Governance has emerged as an additional concept, which some see as an enrichment of the new public management (NPM) philosophy, others as a paradigmatic shift towards a more outward focused public sector, emphasizing co-operation, democracy and citizen participation (McBain, 2010).

In this present era, accountability term in indonesia's public sector is not a strange and new thing. Almost all government agency emphasize on accountability in performing administrative functions. Accountability has become an icon for good governance both in the public and in the private sector (Bovens, 2007). This phenomenon affected by Indonesian government reform in 1998. Before the refom begin, the lack of

* Corresponding author. e-mail: bangpray87@gmail.com accountability and trasparency considered to be the main cause for the economy crisis. To fix the condition, some international organizations such as World Bank and IMF give financial aid and in the return give influence in the form of doctrine to improve the accountability both in private sector and public sector. The dissatisfaction of the old governance system, evoke the needs of new system to run the government. The rise of the NPM promotes the replication of the private sector style inside the public sector (Lapsley, et al, 2009; Hood, 1995). NPM is the new approach in public sector management that appeared to critizised classic bureaucracy. Those critics trigger the reform of public sector management to adopt private sector management technique including give more attention to the a NPM paradigm has made a difference to the way of management and public sector administration, making it more rational and economical in facing the demand and expectation from the people (Hood, 1995). In this paradigm, accountability style become more managerial and specifically must be able to show the output and achievement of outcome from government program or activities. This transformation in the end also brings significant change to public accountability, and in it also included financial accountability and managerial. Accountability is not just about the management of public funds, more than that government expected to 
utilized the public funds effectively and efficiently (Guthrie, 1998; Karan, 2003).

In Indonesia, the effort to increase the accountability and realize the good governance called reformasi birokrasi (bureaucratic reform). This bureaucratic reform inisiated with the publish of Law 28/1999 about Penyelenggaraan Negara yang Bersih dan Bebas dari KKN. As a form of implementation of reforms in the field of financial management, the government issued laws in management of nation finances; Law 17/2003 about Keuangan Negara, Law 1/2004 about Perbendaharaan Negara, and Law 15/2004 about Pemeriksaan dan Tanggung Jawab Keuangan Negara for check and balance system Achievement of performance and accountability.

After more than one decade of implementation of bureaucratic reform in Indonesia, some fact shows that public sector accountability still far from expected. Target achievement of the goals contained in Rencana Pembangunan Jangka Menengah (RPJMN) tahun 20102014 one of them is the realization of a clean government and free from corruption, collution, and nepotism with the indicator of audit opinion from Badan Pemeriksa Keuangan (BPK) is unqualified opinion for central government (LKPP) is $100 \%$ and local government (LKPD) is 34\%, but until the end of 2014, those target has not been reached with only $74 \%$ for LKPP and $34 \%$ for LKPD. Inability to achieve the target means financial accountability and managerial from both central government and local government is still far from expected.

The making of financial statements is a form of transparency and an indicator of accountability in the form of government openness in public source management. The government should provide the public with complete information on its past, present, and projected fiscal activities (Allen, Schiavo-Campo, and Garrity, 2004). Today, the government already have their own Government Accounting Standard (SAP) as the accounting principle that used to compile and present the financial statement (Government regulation 24/2005). Since 2015, acc In order to implement accrual basis accounting, as mandated in Law 17/2003 and Law $1 / 2004$, the government has establish Government Regulation 71/2010 about Standar Akuntansi Pemerintahan. Those regulation regulate Government Accounting Standard (SAP) on accrual basis and SAP on cash basis towards accrual. In accordance with the regulation, government apply SAP on accrual basis gradually under the condition full implementation of SAP on accrual basis no later than fiscal year 2015. Over the circumstances, accrual basis of accounting has been applied in Laporan Keuangan Pemerintah Pusat (LKPP). Simply, the application of accrual basis of accounting addressed to resolve inadequacy of cash basis accounting in providing more accurate data.

The result from the financial statement is vary each year. From 2012 to 2014 the opinion from BPK is unqualified opinion (WTP), but in 2015 the assesment dropped to qualified opinion (WDP) and back to WTP again in 2016. If the strategic management of an organization is not executed properly, the previous conditions that affects the making of financial statement in Ministry of Foreign Affairs will occured again and resulted in decrease on audit opinion from BPK. Given the enormous demands to achive WTP from BPK, Ministry of Foreign Affairs needs to utilize strategic management process in the making of their financial report. Therefore, this research aim to study about the strategic management of Ministry of Foreign Affairs in the making of financial statement.

\section{Theory}

\subsection{Management}

According to Brantas (2009), management is a process or an working framework that include guidance or directions of one group of people towards organizational goals or real intentions. Next, Siswanto (2009) said that management is science and art to perform action in achieving the goals. This is confirmned by Waluyo (2007), Management is process of planning, organizing, directing, and controlling of organizational effort and the process of the utilization of every organization sources in order to achieve organizational goals that have been set before.

Furthermore, Heene et all (2010) explain that management is the series of continous human activities in achieving the goals that have been set. Those activities divided into specific functions; planning, organizing, leading, controlling.

\subsection{Strategy}

There are some definition of strategy as stated by the experts in their own book. Strategy originated from greek word, strategos which is the reslut of combining two words stratos and ego. A strategy have a basic or scheme to achieve the target goals. So basically strategy is a tool to achieve goals. The definion of strategy later develop in lie with the opinion from John Von Neumann, a mathematician anf Oskar Morgenstern an econimist. They include games term and the real factor of the game itself. The also admitted that games theory actually a strategic theory. Strategic theory stated that there are two main attribute that need to be remember, skills and opportunity where both is a contribution in every strategic situation. Strategic situation is a situation where two or more people interact and rely each other action on other people action that cant be controlled, and the result depend on gestures from each cast (salusu, 2003).

\subsection{Strategic Management and its Characteristic}

Strategic management itself can be interpreted as a managerial action that tries to develop the potential of the organization in exploiting organizational opportunities that appeared to achieve organization goals that have been established.

Coulter (2013) in her book Strategic Management in Action explain that strategic management is important 
for an organizational success. These are the reason why it is important:

a) Understanding how and why strategic decisions are made will help to $\mathrm{d}$ job well and make work valued and rewarded accordingly.

b) Strategic management doed appear to make a difference in how well anorganization performs. Organization that use strategic management tend to have higher level of performance, usually measured as "bottom line" or profits.

c) The deliberate structure of the strategic management guides organizational decision makers inexamining important issues to determine the mosr appropriate strategic decisions and actions. It will help prganzations of all types and sizes face continually changing situations both externally and internally.

d) Strategic management process help the organization to fill the process of coordinating of organizational structureand focused on achieving the organization's goals. It can ensure that their actions are coordinated.

According to Coulter (2013), strategic management has four characteristics. Coulter explained those characteristics, first, it doesn't focus on any specific organizational area but instead encompasses all the functional areas or it called as interdiciplinary. Second, it has an external focus, it involves the interactions of the organization with its external environment. Third, it also has an internal focus, which involves assessing the organization's resources an capabilities. Finally, it involves the future direction of the organization. The future can mean weekly, monthly, yearly or significant long ter, shifts in the organization's product.

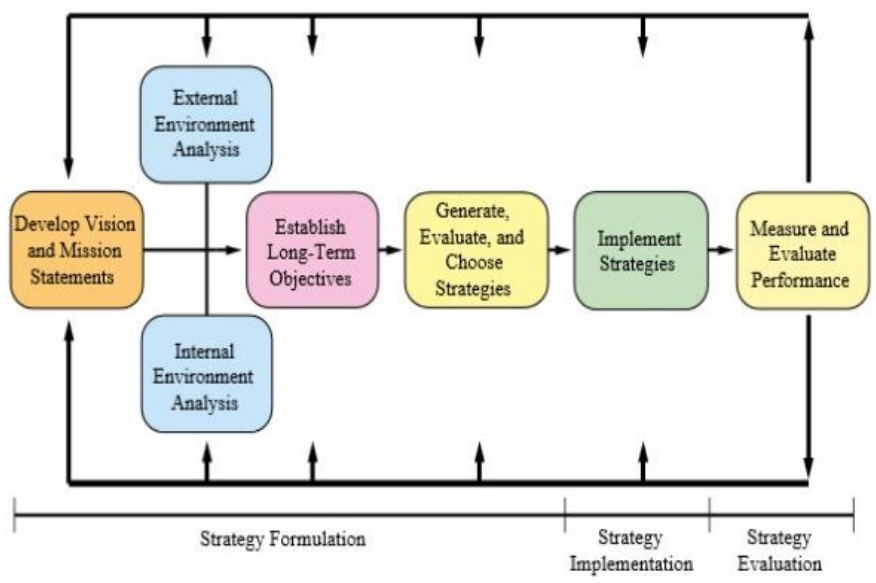

Figure 2.1. Model of The Strategic Management Process Source: Jurevicius, 2013

David (2011) explain more further (figure 2.1), he stated that strategic management can be defined as the art and science of formulating, implementing, and evaluating cross-functional decisions that enable an organization to achieve its objectives. He also explain that strategic management process consists of three steps, strategy formulation, strategy implementation, and strategy evaluation.

Started from strategy formulation, the process needs to be done well in order to answer the problems encountered and reflect vision and mission from an organization. The first step in forming a strategy is to review the information gleaned from completing the analysis. Determine what resources the business currently has that can help reach the defined goals and objectives On the next step, the implementation from the strategy is an answer of desired condition. Implementation step is a combination from various source to be utilized as best as possible with minimalize errors and improve effectiveness and efficiency. The next is evaluation step that must be done continously so that the strategy get improvement from time to time, because the change will always happen. This is the step that taken by leader of the organization to achieve their vision, goal and target with due regard from the beginning of the process the stragey is formulated to the last step of evaluation, so the obstacles and problems that occured can be overcome.

\section{Research Method}

\subsection{Research Type}

This study used qualitative approach by using single case study in Financial Bureau, Secretariat General, Ministry of Forreign Affairs, Indonesia.

\subsection{Research Focus}

The study focuses on the strategic managemet. Moreover, each stage in this process used David's approach (2011) consisting of 3 steps as follow:

a) Strategy formulation;

b) Strategy implementation; and

c) Strategy evaluation.

\subsection{Data Collection Technics}

The data was collected by using documentation and observation.

\section{Description of The Research Site}

\subsection{Overview Ministry of Foreign Affairs}

The Ministry of Foreign Affairs of the Republic of Indonesia, is a ministry within the Government of Indonesia in charge of foreign affairs. The Ministry of Foreign Affairs is chaired by Retno Marsudi as a Foreign Minister from 27 October 2014 and Vice Minister Abdurrahman Mohammad Fachir who was inaugurated by President Joko Widodo since 27 October 2014 simultaneously with the inauguration of the Cabinet of Work Ministers. The Ministry of Foreign Affairs is one of three ministries (together with the Ministry of Home Affairs and the Ministry of Defense) mentioned explicitly in the 1945 Constitution. The Foreign Ministry can not be changed or dissolved by the president. The Minister of Foreign Affairs jointly with the Minister of Home Affairs and the Minister of Defense acts as the executor of the duties of the presidency if the President and Vice President die, cease, dismiss, or can not perform his duties in his term simultaneously. 
On August 19, 1945 after the Proclamation of August 17, 1945, the Ministry of Foreign Affairs is set up in the Presidential Cabinet and was the first cabinet after the proclamation of the Republic of Indonesia on August 17, 1945. In the development once called the "department", then based on the Law 39/2008 it changed to Ministry of Foreign Affairs.

\subsection{Job and Functions}

The Ministry of Foreign Affairs of the Republic of Indonesia has the task of organizing government affairs in the field of politics and foreign relations in government to assist the President in organizing the central government. In carrying out the duties, the Ministry of Foreign Affairs of Indonesia performs the functions of: Formulation, establishment, and implementation of policies in the field of politics and foreign relations; Management of state property which is the responsibility of the Ministry of Foreign Affairs; Supervision on the execution of duties within the Ministry of Foreign Affairs; and Implementation of technical activities from central to regional.

\subsection{Secretariat General}

As part of the Ministry of Foreign Affairs, the secretariat general has tasks and functions in facilitating and supporting the fulfillment of the needs of the leadership of the Ministry of Foreign Affairs. In the implementation of the task, The Secretariat General continues its efforts to realize a performance management system based on planning, performance measurement, execution, and control internal evaluation in accordance with SAKIP in order to realize that institution professional, clean and authoritative and apply the principles of good governance.

\subsection{Job and Function of Secretariat General}

Based on the Regulation of the Minister of Foreign Affairs 2/2016 about Organization and Working Procedures of the Ministry of Foreign Affairs, duties and functions of the secretariat general are:

\section{a) Job}

The secretariat general has the duty to organize coordination of implementation tasks, guidance, and administration support to all elements of organizations within the Ministry of Foreign Affairs and Representatives of the Republic Indonesia.

b) Function

- Coordination of activities of the Foreign Ministry and Representative of the Republic Indonesia.

- Coordination and preparation of plans, programs, and budgets of the Ministry of Foreign Affairs and the Representative of the Republic of Indonesia.

- Guiding and providing administrative support covering the administration, employment, finance, household, cooperation, public relations, archives, and documentation of the Foreign
Ministries and Republican Representatives Indonesia.

- Guiding and structuring the organization and administration of the Ministry of Foreign Affairs and the Representative of the Republic of Indonesia.

- Coordination and drafting of legislation and implementation of legal advocacy.

- Management of state property and goods/ services procurement of the Ministry of Foreign Affairs and the Representative Republic of Indonesia.

- The implementation of other functions given by the Minister.

\subsection{Strategic Aspects of the Organization}

The Secretariat General has the main duties in carrying out the coordination of the implementation of duties as well as the guidance and provision of management and administrative support of the Ministry of Foreign Affairs. In its task of implementing human resource management support, the Secretariat General has an important role in managing competent human resources of Foreign Ministry including the employees who are fostered and developed their potential and can meet the criteria of internal conditions that include knowledge, skills, interpersonal and intrapersonal elements capable of supporting the achievement of organizational performance optimally.

The Secretariat General also has a strategic role in managing the optimal budget with maximum budget absorption and fulfillment of the targeted performance targets. In addition, the Secretariat General also plays a role in the management of integrated management information systems, effective and efficient use of information and communication technology in order to support the implementation of the Foreign Ministry's strategy. The integration of management information systems can result in the effectiveness of information systems, so that the exchange of data / information can take place quickly and accurately, to encourage the creation of accountability, transparency, efficiency, and effectiveness of performance, and encourage improving the quality of public services Ministry of Foreign Affairs.

\section{Results and Discussion}

\subsection{Formulating the Strategy}

The first step of strategic management arrangement process is setting the organizations' objectives because the key component of any strategy statement is to set the long-term objectives of the organization. It is known that strategy is generally a medium for realization of organizational objectives. Objectives stress the state of being there whereas Strategy stresses upon the process of reaching there. Strategy includes both the fixation of objectives as well the medium to be used to realize those objectives. Thus, strategy is a wider term which believes in the manner of deployment of resources so as to achieve the objectives. In arranging strategic management plan, Head of Financial Bureau Controlling as the organization's leader is the first 
actor who initiated it base on the goals of the organization. Moreover, organization's leader would negotiate and explain of strategic planning process comprehensively to all parties.

Nevertheless, in practice, this task was tackled by his subordinate (Head of Accounting and Reporting Division) due to the core responsible is closely related to the arrangement of finacial statement document. After that, he continued with establishing a special team called Tim LK consisting of some organization's members, such as Head of Accounting and Reporting Division as the team leader and all representative from Budget Implementation Division, Budget Control Division, Budget Verification Division, Accounting and Reporting Division, and Treasury Division.

After the team was officially exist, they started to find and to collect materials for the document from internal and external organization. The involvement of external stakeholder and another internal stakeholder also important and hold a crucial role to enrich and to support internal data. Those stakeholders consist of:

\section{a) Internal Stakeholder}

Coordination were conducted by Financial Bureau with another unit within Secretariat General, Inspectorate General and all Directorate General in the Ministry of Foreign Affairs.

\section{b) External Stakeholder}

Coordination and cooperation were conducted by Financial Bureau with Directorate of Accounting and Financial Reporting of Ministry of Finance and BPK.

Second is evaluating the environment in which the organization operates. This to know how the condition of the organization and what are the factor that influence it. Theoretically, strategic issues are identified after SWOT analysis has been conducted (Yosandi, 2017). Basically, SWOT can be used to generate many possibilities of alternative strategies through this matrix. The TOWS matrix illustrates four types alternative strategies by combining internal and external aspect of organization for instances SO (strengthopportunities) strategies maximizing strength and opportunity aspects; WO (weaknesses-opportunities) strategies that minimize weakness and maximize opportunity aspects; ST (strengths-threats) strategies that maximize strength and minimize threat aspects; and WT (weaknesses-threats) strategies minimizing weakness and threat aspects (Wheelen and Hunger, 2012). The most difficult part in developing strategies by using TOWS is about how to match between key internal and external factors. This is important due to good judgement and interpretation from the strategic plan team is needed (David, 2011). But in this study, the researcher didn't find any kind of SWOT analysis. The strategic issues process are conducted by relying to the previous experience and too dependent to the help from Directorate of Accounting and Financial Reporting and also only use a list consisting of all activities regarding to making a financial statement.

According to Bloom's, greater ownership and accountability from all stakeholders can be achieved if all internal and external stakeholders are involved in the process of strategic plan arrangement (Bogue \& Hall, 2003). This underlies the decision to involve all of related stakeholder.

The external analysis conducted with the help of Directorate of Accounting and Financial Reporting as the regulator. Meetings between both side resulted in the planning on how the process of making the financial statement will be done. Directorate of Accounting and Financial Reporting also give the training to the member of Tim LK so they have proper knowlegde in making the financial statement as mentioned in Government Regulation 71/2010, so they can meet the standard set by BPK.

The next step is conducting a performance analysis which includes discovering and analyzing the gap between the planned or desired performance. A critical evaluation of the organizations past performance, present condition and the desired future conditions must be done by the organization. This critical evaluation identifies the degree of gap that persists between the actual reality and the long-term aspirations of the organization. An attempt is made by the organization to estimate its probable future condition if the current trends persist.

Then the next step in Strategy Formulation is to choose the best course of action after considering organizational goals, organizational strengths, potential and limitations as well as the external opportunities.

After that, the next step is to coordinate and socialize the result of consultation with the external stakeholder to the internal stakeholder, because all of those work unit will provide data for Financial Bureau to make the financial statement. Time table is set to give clear schedule because there are deadlines to meet. And this coordination is needed to synchronize the vision and mission to achieve one goal.

\subsection{Strategy Implementation}

The second stage of strategic management, after strategy formulation, is "strategy implementation" or, what is more familiar to some as "strategy execution". This is where the real action takes place in the strategic management process, since this is where the tactics in the strategic plan will be transformed into actions or actual performance.

Strategy implementation is defined as "the communication, interpretation, adoption, and enactment of strategic plans" (Noble, 1999) and is widely perceived to be a significant determinant of performance. If strategy formulation tackles the "what" and "why" of the activities of the organization, strategy implementation is all about "how" the activities will be carried out, "who" will perform them, "when" and how often will they be performed, and "where" will the 
activities be conducted. So in this phase the Financial Bureau communicate the plan to all work unit within Ministry of Foreign Affairs by making the circular letter to socialize and also invite those work unit to attend the meeting and socialization of the strategy.

The style of implementation is important as Long and Franklin (2004) state that a key variable when studying implementation is the approach that each agency uses to implement policy. To focus on the style of implementation within organizations, the processes used to put strategy into practice we draw largely on the literature on strategy implementation and to a lesser extent on the management of change, rather than research on policy implementation, which has typically examined interorganizational relationships (Hill \& Hupe, 2002, Pressman \& Wildavsky, 1984).

Communicate and clarify the goals, objectives and strategies to all members of the organization is necesssary. Regardless of their position in the organization's hierarchy, everyone must know and understand the goals and objectives of the organization, and the strategies that will be employed to achieve them. After socializing the strategy, the Financial Bureau gather all the work unit together and divide in groups. Then they collect the data necessary in the making financial statement guided by the Tim LK. And after the data is finished collected, the Finanfial Bureau consult with BPK so the construction is correct with the help from Directorate of Accounting and Financial Reporting.

Strategy implementation is the stage that demands participation of the entire organization. Formulation of the strategies are mostly in the hands of the strategic management team, with the aid of senior management and key employees. When it comes to implementation, however, it is the workforce that will execute the strategic plan, with top or senior management taking the lead.

\subsection{Strategy Evaluation}

Strategy Evaluation is as significant as strategy formulation because it throws light on the efficiency and effectiveness of the comprehensive plans in achieving the desired results. The managers can also assess the appropriateness of the current strategy in todays dynamic world with socio-economic, political and technological innovations. Strategic Evaluation is the final phase of strategic management.

The standard performance is a bench mark with which the actual performance is to be compared. The reporting and communication system help in measuring the performance. If appropriate means are available for measuring the performance and if the standards are set in the right manner, strategy evaluation becomes easier. But various factors such as managers contribution are difficult to measure. Similarly divisional performance is sometimes difficult to measure as compared to individual performance. Thus, variable objectives must be created against which measurement of performance can be done. The measurement must be done at right time else evaluation will not meet its purpose.

Evaluation will test results from implementation by comparing actual outputs, outcomes, and impacts against planned outputs, desired outcomes and desired impacts (Bliss, 2013). The result of the making of financial report is an audited financial statement. The indicator is what opinion acquired by the Ministry of Foreign Affairs. There are 4 type of opinion from BPK from best to worst: unqualified opinion (WTP), qualified opinion (WDP), adversed opinion, disclaimer of opinion. If the opinion from BPK is WTP (same as last year), the strategy is considered good, but if the opinion is lower, for example WDP, the strategy is considered to be failed and needs an improvement. Because the goal is to achieve the highest opinion which is unqualified opinion.

After your evaluation has considered all of the organizations' historical performance data, the next step is determine what corrective measures should be taken to insure organization operations are correctly aligned with the strategic plan. Many times making corrections to strategic operations will force changes that will cause objections, yet change is an essential element of the controlling process.

\section{Conclusion}

The principles of strategic management in public sector have not been fully adopted by Fiinancial Bureau of Ministry of Foreign Affairs as one of the public organizations in Indonesia. Each step in strategic management process has been summarized as follows:

\section{a) Formulating the Strategy}

In arranging strategic management process of makin the financial statement, the head of Financial Bureau Controlling is the first who initiated it. The SWOT analysis as one of the way to provide data to formulate the strategy is not yet implemented.

\section{b) Strategy Implementation}

Socialization by the letter and meeting were conducted so the strategy that has been produced are known by all work units, so the process of strategy implementation to achieve the goal can be run smoothly.

\section{c) Strategy Evaluation}

The indicator that the strategy is worked is when the BPK give unqualified opinion to the financial statement of Ministry of Foreign Affairs. On the contrary if the opinion is worst than unqualified opinion, the strategy needs to be fixed and further analysis needs to be done.

\section{References}

Allen, Richard; Schiavo-Campo, Salvatore; Columkill Garrity, Thomas. (2004). Assessing and Reforming Public Financial Management: A New Approach. Washington, DC: World Bank. 
Bliss, Keith. (2013). Framework for the Strategic Planning \& Evaluation of Public Diplomacy. NATO, Joint Analysis and Lessons Learned Centre, Lisbon (Portugal).

Bogue, Ernest Grady., \& Hall, Kimberely Bingham. Quality and Accountability in Higher Education: Improving Policy, Enhancing Performance. Westport, Connecticut: Greenwood Publishing Group.

Bovens, Mark. (2007). Analysing and Assessing Accountability: A Conceptual Framework. European Law Journal, Vol. 13 (4), pp.447- 468.

Brantas. (2009). Dasar-dasar Manajemen. Bandung: Alfabeta

Coulter, Mary. (2013). Strategic Management in Action. New Jersey (USA).Pearson Education

David, F.R. (2011). Strategic Management: Concepts and Cases, Thirteenth Edition. New Jersey (USA): Pearson International Edition. (2009). New Public Management: The Cruellest Invention of The Human Spirit?. Abacus, Vol. 45, No. 1, pp.1-21.

Guthrie, J. (1998). Application of Accrual Accounting in the Australian Public Sector - Rhetoric or Reality? Financial Accountability and Management, Vol. 14, No. 1, pp.1-19.

Heene, Aime., \& Desmidt, Sebastian. (20100. Manajemen Strategik Keorganisasian Publik, dialihbahasakan oleh Faisal Afiff. Bandung: PT. Refika Aditama.

Hill, M., \& Hupe, P. (2002). Implementing public policy. London, England: SAGE.

Hood, C. (1995). The "New Public Management" in the 1980s: Variations on a Theme. Accounting Organizations and Society, Vol. 20, No. 2-3, pp.93-109.

Jurevicius, Ovidijus. (2013). Strategic Management \& Strategic Planning Process. Available at https://www.strategicmanagementinsight.com/top ics/strategic-planning-process.html [Accessed 15 on August 2018].

Karan, R. (2003). Selective Commercialisation of Public-Sector Accounting and its Consequences for Public Accountability. Australian Accounting Review, Vol. 13, No. 3, pp.15-25.

Lapsley, I., Mussari, R., \& Paulsson, G. (2009). On the Adoption of Accrual Accounting in the Public Sector: A Self-evident and Problematic Reform. European Accounting Review, Vol. 18, No. 4, pp.719-723.

Long, E., \& Franklin, A. L. (2004). The Paradox of Implementing The Government Performance and Results Act: Top-Down Direction For Bottom-up Implementation. Public Administration Review, 64, pp.309-319.

Mc Bain, Luke. (2010). Strategic Management In The Public Sector. Available at https://www.gcasa.com/conferences/singapore/pa pers_in_pdf/mon/McBain.pdf [Accessed on 11 August 2017].

Noble, C.H. (1999). The Eclectic Roots of Strategy Implementation Research. Journal of Business Research, Vol. 45, pp.119-134.
Pressman, J. L., \& Wildavsky, A. (1984). Implementation (3rd ed.). Berkeley: University of California Press.

Salusu, J. (2003). Pengambilan Keputusan Stratejik Untuk Organisasi Publik dan Organisasi Nonprofit. Jakarta: Grasindo.

Siswanto, H. B. (2009). Pengantar Manajemen. Bumi Aksara, Jakarta.

Waluyo. (2007). Manajemen Publik Konsep Aplikasi dan Implementasi dalam Pelaksanaan Otonomi Daerah. Mandar Maju, Bandung.

Wheelen, Thomas L., \& Hunger, J. David. (2012). Strategic Management and Business Policy: Toward Global Sustainability, 13th Edition. Perason, US.

Yosandi. (2017). Strategic Planning Adoption in Public Organization in Indonesia. Jurnal Ilmiah Administrasi Publik, Vol. 3 (3), pp. 261-268. 